\title{
Article \\ Identity and European Public Spheres in the Context of Social Media and Information Disorder
}

\author{
Jan Erik Kermer and Rolf A. Nijmeijer * \\ Department of Political Science, LUISS Guido Carli University, 00197 Rome, Italy; E-Mails: j.kermer@luiss.it (J.E.K.), \\ r.nijmeijer@luiss.it (R.A.N.) \\ * Corresponding author
}

Submitted: 15 April 2020 | Accepted: 4 June 2020 | Published: 8 October 2020

\begin{abstract}
It was expected that the increasing coverage of EU affairs in national public spheres would lead to a greater sense of European belonging. The Internet was expected to foster this process. However, these expectations do not square with the current political climate of identity politics and the revitalisation of nationalism. How can this incongruence between theory and reality be understood? An intervening variable has added an unpredictability to the mix: information disorder. It is our view that this theory needs revising to include other intervening variables such as social media and information disorder. In this article, we argue that the current dynamic of Europeanised political communication is likely to compromise the civic and vertical components of EU-identity.
\end{abstract}

\section{Keywords}

Europeanisation; information disorder; public sphere; social media

\section{Issue}

This article is part of the issue "The Ongoing Transformation of the Digital Public Sphere" edited by Emiliana De Blasio (LUISS University, Italy), Marianne Kneuer (Hildesheim University, Germany), Wolf J. Schünemann (Hildesheim University, Germany) and Michele Sorice (LUISS University, Italy).

(C) 2020 by the authors; licensee Cogitatio (Lisbon, Portugal). This article is licensed under a Creative Commons Attribution 4.0 International License (CC BY).

\section{Introduction}

Most scholars agree that 'European identity' and the 'Europeanised public sphere' exist in some shape or form (e.g., Risse, 2010). Studies have shown that EU affairs are becoming more salient in the national public spheres that comprise Europe (Eder \& Kantner, 2000; Kriesi \& Grande, 2012; Risse, 2010). These concepts share three things in common: their definitions are hotly contested; they are understood to be socially constructed; and they are being increasingly co-opted by European studies scholars (e.g., Machill, Beiler, \& Fischer, 2006). This is unsurprising given the growing consensus of 'postfunctionalism' which posits that further integration is contingent on the general publics' receptiveness to other levels of attachment. However, post-functionalists ignore an elephant in the room: the mass media (de Wilde,
2019). The latter is, after all, the linchpin connecting political actors to civil society. Nonetheless, postfunctionalists - and their derivatives - widely agree that 'feeling' a sense of belonging to Europe is axiomatic to the prospects of 'ever closer union.' In recent years, 'politicisation' has entered the academic fold for its normative potential to popularise European affairs and foster transnational communication. Some scholars even claim that the increasingly transnational setting of public spheres and politicisation can foster a European identity (e.g., Eilders \& Lichtenstein, 2010). Our article critically evaluates the latter claim which belies the complexities of an increasingly chaotic social world. We therefore urge scholars to consider the phenomenon of online 'information disorder' on social media, which we argue, has a destabilising effect on the transnational public spheres' functioning and ergo post-national identity formation. 


\section{The Concept of European Identity and the European Public Sphere}

\subsection{European Identity}

In its broadest sense, European identity means a sense of attachment to Europe which is understood either as a cultural, geographical, and/or political entity. This is an uncontroversial definition, but it still tells us little about the concept's intensionality. As with most concepts, things get complex as one descends the ladder of abstraction. European identity is a widely contested and elusive concept, and endeavouring to define it in a few lines would belie its complexity. We therefore focus on the concepts common-denominator dimensions. Bruter's (2003) distinction between civic and cultural components is an instructive starting point. The former is understood as "the degree to which they see themselves as citizens of a European political system, whose rules, laws, and rights have an influence on their daily life" (Thomassen, 2009 , p. 188). The latter "may be defined as an individual citizen's identification with a particular social group" (MacMillan, 2013, p. 59). Cultural identity can be constructed inclusively in terms of universal or cosmopolitan values, or exclusively through (sub-)nationalistic or 'Fortress Europe'-type frames. Generally speaking, cultural identity is more prone to exclusivity as culture is habitually understood as an autochthonous set of norms, behaviours, and practices. On the contrary, civic identity is generally more receptive to 'outsiders' as the latter can adopt the laws and institutions of the host identity. Moreover, citizenship can, in theory, be legally amended to accommodate 'outsiders' and culturally heterogenous groups. EU citizenship is a paradigmatic example of the latter. In light of studies from social psychology, individuals tend to identify both with their nation, first and foremost, and the EU, secondly, when the latter's civic or cultural identity is congruent with their national identity. Conversely, when the EU and the nation are constructed incompatibly in respect of laws, institutions, goals and values, exclusive identities become more likely (Wenzel, Mummendey, \& Waldzus, 2007).

In order to delimit the scope of our argument, we distinguish between vertical and horizontal identity: the former consists of dually identifying with one's nation and the EU, whereas the latter consists in identifying both with one's nation and other European countries or Europe as a whole. However, these horizontal and vertical identities are not mutually exclusive. In fact, politicians and the mass media generally use the terms 'EU' and 'Europe' interchangeably. Pro-Europeans tend to equate EU-scepticism with the lack of identification with Europe; however, it is logically conceivable to hold anti-EU sentiments and still 'feel' European in the horizontal sense. We argue that the current dynamic of Europeanised political communication is likely to compromise the civic and vertical components of EU-identity. A caveat is in order: Civic and cultural identity are not mu- tually exclusive and may overlap. Indeed, we even countenance the possibility of national cultural-identitarian frames adversely affecting civic attachment to the EU whilst leaving 'Fortress European' identity intact. The bottom line is identity is a multifaceted and complex phenomenon, particularly when levels of attachment beyond the nation state are considered. We therefore delimit our argument to the civic dimension as previous studies (see Bruter, 2003) have demonstrated that EU news predominantly affects the civic components of identity, and EU news coverage largely manifests as a vertical constellation of national actors addressing EU-level actors (Koopmans \& Statham, 2010).

\subsection{European Public Sphere}

As with identity, the Europeanised public sphere is a conceptual black box. Trenz (2008b, p. 278) broadly defines the Europeanised public sphere as a "process that enlarges the scope of public discourse beyond the territorial nation state." Although scholars disagree on its normative dimensions, most scholars agree on what Europeanised public sphere's look like. A panoply of different adjectives have been iterated to describe the public sphere: 'fragmented,' 'anarchic,' 'differentiated' (E. O. Eriksen, 2007), 'heterogenous,' 'agonistic' (Mouffe, 2007), 'pluralistic' (Sicakkan, 2012), 'polymorphic,' 'polyphonic' (Fossum \& Schlesinger, 2007), and so on. The common denominator of these superlatives are the public spheres' lack of uniformity and unitarity. It is widely accepted that all public spheres have historically fallen short of their normative ideals. For example, when judged against the normative benchmark of inclusiveness and accessibility, we can confidently assert that the 18th century 'bourgeois public sphere' (the 'bürgerliche Öffentlichkeit' in German) never existed, as women and the working class were largely disenfranchised from participating in public debates. However, many concepts exist along a continuum from minimum to ideal-type requirements. 'Europeanisation,' 'democracy,' and 'public sphere' are three apposite examples. Our argument is thus predicated on an empirical understanding of the deliberative public sphere model. Based on the findings from psychological and media studies on information consumption and processing, we countenance an agonistic and irrational model of the public sphere. An ideal public sphere presupposes respectful debate thereby leading to rational assessment and the internalisation of information. However, this does not necessarily materialise in actual discourse, particularly regarding the framing of European identity. Moreover, recent studies-examining how humans process and internalise information-reveal an individual's proclivity to modify newly acquired information in order to reinforce pre-existing beliefs (Southwell, Thorson, \& Sheble, 2017). However, we acknowledge that a normative checklist is necessary prior to establishing if the phenomenon in question exists. We therefore turn our attention to the 
minimum normative requirements of the Europeanised public sphere.

A Europeanised public sphere should contain the 'same issues' (what Medrano, 2003, calls 'thematische Synchronizität') at the 'same time' (Eder \& Kantner, 2000) and employ 'similar aspects of relevance' (Adam, 2012; Eder \& Kantner, 2000; E. O. Eriksen, 2007; Lindner, Korthagen, \& Aichholzer, 2018), that is, "with similar frames of interpretation but not necessarily with the same opinions" (Kantner, 2015, p. 87). However, these conditions are not sufficient in themselves, as the "parallelisation' of national debates can still suffice without the spherical levels 'interacting' or 'overlapping' with one another (Nitoiu, 2013; Wessler, Peters, Brüggemann, Kleinen-von Königslöw, \& Sifft, 2008). The Eder-Kantner formulation lacks the dimension of 'communicative linkages' between speakers across different spherical levels (Koopmans \& Statham, 2010; Pfetsch, 2004). This has led some scholars to insist on "discursive interchange" (Adam, 2012) or "increasing mutual interconnections between national public spheres" (Brantner, Dietrich, \& Saurwein, 2005, p. 8). Europeanisation is understood as a bi-directional process which implies a continuum from minimum (i.e., visibility of EU actors and interconnectivity) to optimal conditions (i.e., references to a common identity, the same frames of references, rational debate, etc.). At a minimum, the first three conditions should be satisfied to be able to talk meaningfully of a Europeanised public sphere. The last requirement, however, distinguishes 'Europeanised national public spheres' from 'nationalised public spheres' reporting European issues more frequently.

With the above in mind, a logical next step is to establish whether a Europeanised public sphere exists in some shape or form. In regard to the first two requirements (see above), several studies have detected 'thematische Synchronizität' across national public spheres (Eder \& Kantner, 2000; Kriesi \& Grande, 2014; Risse, 2010; Trenz, 2008b). Concerning the third requirement, it has been consistently demonstrated that-as far as newspapers (Bossetta \& Segesten, 2019; Koopmans \& Pfetsch, 2003; Pfetsch, 2004), television (Brantner et al., 2005; Grill \& Boomgaarden, 2017) and social media (Hänska \& Bauchowitz, 2019) are concerned-national public spheres are embedded within a larger European network of communication. It is less clear whether the fourth condition has been satisfied although most studies conclude that there are converging 'structures of meaning' across national media arenas (Bärenreuter, Brüll, Mokre, \& Wahl-Jorgensen, 2009; Bossetta \& Segesten, 2019; Eder \& Kantner, 2000; Kantner, 2016; Risse, 2010, 2014). The most notable critics of this view are Medrano and Gray (2010) and Statham (2007) who found discernible cross-national differences in how the EU is represented. We can tentatively conclude, in light of a review of the literature, that a thin veneer of Europeanisation exists, notwithstanding the fact that national public spheres are still heavily embedded in national communicative structures. We therefore doubt the suppositions of deliberative scholars who claim that the current setting of Europeanised public spheres are conducive to forging a European identity.

\section{The Public Sphere and Identity in the Digital Age: Theoretical Background}

One thing most scholars can agree on is public spheres affect identities in some shape or form. Social constructivism is currently the dominant paradigm on approaches to identity (E. O. Eriksen, 2007; Heller \& Rényi, 2008; MacMillan, 2013). Communication scholars have underlined different aspects of communication as crucial to the congealment of identity, such as: 'discourse' (Fearon \& Laitin, 2000; Wodak, 2007); 'narratives' (Eder, 2009; Loseke, 2007; Scalise, 2013), and 'deliberation' (Dewey, 1927; Risse, 2014). Scholars such as Derrida emphasise the performative and enacting quality of discourses (Derrida, 1988). In a similar vein, Delanty posits that social identity is sustained by what he calls 'dialogic identity' (Delanty, 2005). Despite their subtle nuances, most constructivists agree that identity is (re-) produced through media communication. The media are not mere purveyors of the news; they determine what is reported (i.e., 'gate-keeping') and how it is reported (i.e., 'agenda-setting') through a panoply of framing devices such as 'valence,' 'sentiment,' and 'issue-framing' (de Vreese \& Kandyla, 2009; Schuck \& de Vreese, 2006; Van Cauwenberghe, Gelders, \& Joris, 2009). The media largely determine what kinds of narratives (Eder, 2009), deictic constellations, and symbols dominate the public sphere (Billig, 1995). Furthermore, editorials render the media as political entrepreneurs in their own right (Voltmer \& Eilders, 2003). The role of the media is even more decisive in a European context as most people can only obtain information about Europe through them. As Risse pithily remarks, "the [European] public sphere is what the media make of it" (Risse, 2010, p. 115).

With social constructivism firmly in the driving seat, scholars have shifted their attention towards the public sphere which is regarded as the locus of national identity formation (de Wilde \& Trenz, 2012; Kleinen-von Königslöw, 2010; Sicakkan, 2012). There is a rich body of scholarship that underlines the co-constitutiveness of national identity and the public sphere. Bauer (1881-1938) was probably one of the first scholars to establish the link between communication and national identity. He argued that the nation was a "community of fate" ("eine Schicksalsgemeinschaft" in German) engaged in "general reciprocal interaction" (Bauer, 2000, as cited in Fossum \& Schlesinger, 2007, p. 70). Similarly, Deutsch posited the theory that national consciousness emerged through strongly bounded patterns of social interaction: "People are held together 'from within' by this communicative efficiency, the complementarity of the communicative facilities acquired by their members" (Deutsch, 1966, 
as cited in Fossum \& Schlesinger, 2007, p. 70). Public spheres were crucial to the construction of a nationally 'imagined community' (Anderson, 1983) through "technically reproduced print languages [that] have unified fields of linguistic exchange, fixed national languages and created idiolects of power" (Anderson, 1983, as cited in Fossum \& Schlesinger, 2007, pp. 70-71). Habermas originally conceived of the 'Öffentlichkeit' as a figurative space located within national boundaries (Habermas, 1991). For him, the public sphere went hand in glove with the rise of the nation state. According to Billig's theory of 'banal nationalism,' nationhood is frequently flagged through the reproduction of national symbols and re-iteration of deixis (i.e., words such as 'our,' 'we,' 'here,' 'this,' 'the nation') that "continually point to the national homeland as the home of the readers" (Billig, 1995, p. 11). Other scholars have underlined the importance of the mass media in crystallising a national consciousness (Cohen, 1994; Gellner, 2006).

However, scholars agree less on whether Europeanised political communication can help forge a European identity. Nonetheless, there are several proponents of this theory (Hennen et al., 2020; Pfetsch, 2005; van Os, 2005; Wodak, 2007). For instance, Eder (2009) argues that European identity emerges through the sharing of European narratives. Risse posits that European identity emerges out of contestation in the Europeanised public sphere: "Debating European issues as European questions...is likely to increase political identification levels with the EU" (Risse, 2014, p. 156). Even the face of neofunctionalism, Haas (1958), envisaged the "shifting of loyalties, expectations and political activities toward a new centre" (i.e., European identity) through socialisation processes in which economic and political interests would converge (Haas, 1958, p. 16). Other scholars underline the importance of 'mediatised discourse' for the congealment of European identity and empirical evidence is aplenty (Olausson, 2010; Scalise, 2013; Triga \& Vadratsikas, 2018; Valentini, 2006). For example, Koopmans and Pfetsch (2003, p. 30) conclude that German quality newspapers "emphasise the collective identities, norms and values that Europe should stand for." Trenz carried out a study into framing concluding that journalists tend to see Europe through a European pair of glasses (Trenz, 2008a). Van Os (2005) identified a general feeling of belonging to Europe among French political parties. Similarly, Van Cauwenberghe et al. (2009) detected thematic synchronicity in EU news coverage across national public spheres. However, one should bear in mind that there is a notable selectivity-bias in the newspapers chosen with tabloids largely neglected from analysis.

Where does the Internet fit into the debate? Before the turn of the millennium, most scholars assumed that the Internet would herald an era of global governance, universal cosmopolitanism, and the rise of post-national identities. McLuhan's (1964) cliché of the 'global village' was the academic watchword, and scholars were optimistic about public spheres' identity-making function. This position is intuitively appealing: In theory, cyberspace is a boundless, de-territorialised infrastructure of communication, and the Internet has dramatically reduced transaction costs of cross-border communication. And, research on social movements has demonstrated the capacity of the Internet to foster transnational identities (Della Porta \& Mosca, 2006). Nonetheless, these expectations do not square with the current political climate of identity politics and the recent revitalisation of nationalism. A combination of increasing politicisation and information disorder on the Internet calls for scholars to re-evaluate the ostensibly linear relationship between the public sphere and identity.

\section{The Europeanisation of Public Spheres and the Thin Prospect of a European Identity}

\subsection{The Re-Structuring of Political Conflict and Identity}

In our view, the relationship between the public sphere and European identity has been overstated. Implicit to the 'Euro-optimistic' standpoint (e.g., Bruter, Risse) is the assumption that transnational political conflict would replicate the left-right contestation seen within national democracies. However, these assumptions do not sit comfortably with the 'transnational/integrationdemarcation' cleavage theses (Hooghe \& Marks, 2017; Kriesi \& Grande, 2006, 2008). To put it crudely, the latter assumes that cultural-identitarian conflicts would prevail over economic-utilitarian ones. Recent empirical evidence lends support to these assumptions. Kriesi and Grande (2012) found that identity has become the most effective political mobiliser of this integrationdemarcation' cleavage. A corollary to the preceding point is to consider what is being contested. Bartolini and Hix (2006) distinguish between two types of contestation: 'isomorphic' and 'constitutive.' The former relates to European issues that closely mirror national issues (e.g., tax reform, welfare policy). Contestation of this kind is typically structured along the left-right dimension which is considered normatively desirable because of its potential to foster transnational left-right coalitions of 'collective action' beyond the nation state (Habermas, 2012). In contrast, constitutive contestation poses questions that strike at the heart of the polity (e.g., questions relating to membership, treaty change, geographical boundaries of the Union etc.). In short, isomorphic contestation challenges policy and constitutive contestation challenges polity. It is difficult to imagine the emergence of a 'thick' European identity in the context of constitutive contestation. The latter is more susceptible to polarising binary categorisations (e.g., 'In/Out' or 'Remain/Leave') as they tend to provoke questions of group membership (i.e., EU membership of Turkey). In contrast, contestation on isomorphic grounds invokes a range of opinions which cannot be easily placed into two opposing camps: Indeed, our assertion appears vin- 
dicated as the left-right dichotomy is beginning to lose some of its explanatory power in predicting electoral trends. It does not follow that isomorphic contestation is not susceptible to polarisation, but we suspect constitutive contestation is more ideologically charged as it tends to elicit questions that touch on the highly emotive question of 'who we are?' (i.e., group membership). And, as Marks and Hooghe (2003) implicitly argue, the prevalence of constitutive contestation is indicative of deficient levels of support for a polity. By the same token, ideological contestation along the left-right dimension only tends to dominate when the boundaries of a polity are accepted (Marks \& Hooghe, 2003). Interestingly, previous studies indicate that Eurosceptic parties tend to focus predominantly on the constitutive issues of membership (Christensen, 1996; Taggart, 1998). This is unsurprising given that the jurisdictional boundaries of the EU are still uncertain. Nonetheless, scholars are right to point out that contestation per se is not necessarily equivalent to being anti-EU (think of 'Euro-criticism') and contestation can be, democratically speaking, normatively desirable (Follesdal, 2014). We expect, however, the predominance of constitutive contestation to adversely affect EU support, and ergo a civic sense of belonging to the EU.

\subsection{Identities: Inclusive, Exclusive, or Both?}

A common denominator of the Euro-optimistic view is conceiving of multiple and inclusive identities. Whether scholars understand multiple identities as 'hierarchical' (i.e., a 'Russian doll,' e.g., national first, Europe second) or 'intertwined' (i.e., a 'marble-cake,' e.g., the enmeshment of national and European identity), most scholars agree that identities are inclusive (Bruter, 2005; Citrin \& Sides, 2004; Marks, 1999; Medrano, 2003; Medrano \& Gutiérrez, 2001; Risse, 2010). Several studies suggest that high levels of national identity are also consistent with strong EU support (cf. Citrin \& Sides, 2004; Marks \& Hooghe, 2003). Eurobarometer surveys have shown that a dual sense of attachment to both the nation and Europe has increased, albeit modestly. This has led to the assumption that the increasing salience of one identity (national or European) in the public sphere would not adversely affect other levels of attachment. However, identities are (re-)produced in many ways and there is no logical reason why this cannot apply to identities of an exclusive kind. In fact, several studies have shown that the Internet is a seedbed for the production of exclusive virtual communities. The kind of identity that is constructed in the public sphere has implications for European integration. A study by Marks and Hooghe (2003) has shown that people who hold an exclusive national identity are less likely to support and identify with the EU (Anderson \& Kaltenthaler, 2001; Deflen \& Pampel, 1996; Klingeren \& Boomgaarden, 2014). The effect is even stronger in countries where EU integration has become politicised (Marks \& Hooghe, 2003).
Furthermore, identities are more likely to be conflictual if national identity is framed in cultural instead of civic terms (Smith, 1992). And socioeconomic factors (e.g., economic decline, migration, etc.) are likely to amplify the effects of exclusive-identity framing, making national identity come into conflict with European identity (Cinpoes, 2008). In sum, a combination of exclusivecultural-identity framing, politicised European debates, and a deteriorating socioeconomic situation, are likely to disrupt the EU integration process. Where does the Internet fit into the triadic relationship between public spheres, politicisation, and identity?

The Internet is likely to foster politicisation for two reasons. Firstly, politicisation, by definition, opens up conflict to new actors (de Wilde \& Leupold, 2015) who have easy access to new mediums of communication in which to participate in debates. Secondly, the Internet is expected to increase polarisation. The Internet is largely unmediated thereby creating a fertile environment for the permeation of divisive discourses. This has enfranchised new voices, many of whom are no friends of European integration. Social media has been found by one study to strengthen the Eurosceptics hand. There is no a priori reason why they should benefit but they have done (TNS Global, as cited in Cerulus, 2015). Moreover, a plethora of studies have shown that the Internet reinforces-or at least, reflects-ethno-cultural identities and can rouse nationalism (Barisione \& Michailidou, 2017; Derman \& Ross, 2003; Koopmans \& Zimmermann, 2003; T. H. Eriksen, 2007). According to several studies, national identity (Miller \& Slater, 2001) and nationalism (Caiani \& Parenti, 2009; Gidişoğlu \& Rızvanoğlu, 2011; T. H. Eriksen, 2007) are thriving on social media (Barisione \& Michailidou, 2017). As Diamandaki puts it, "the Internet-a placeless medium-allows for the (re)creation of place...[cyberspace is] another archive, mirror, and laboratory for the negotiation of national and ethnic identity" (Diamandaki, 2003, pp. 3-4). Without explicitly addressing the public sphere and identity debate, these studies contradict the notion of the Internet as a 'global village.' Notwithstanding this, we acknowledge that it is probably too hasty to jump to the conclusion that the Internet serves to embolden national allegiances of an exclusive kind (Gidişoğlu \& Rızvanoğlu, 2011; T. H. Eriksen, 2007). There are several caveats: Firstly, participation in cyberspace still represents a fraction of civil society, and questions can be raised about the generalisability of these findings beyond the cases studied; secondly, we cannot demonstratively claim that a collective identity would emerge or whether they merely reflect pre-existing identities emanating from a negligible minority; lastly, assuming that online communities foster offline identities, we cannot confidently assert that these identities would be of an exclusive kind as offline interactions might override these sentiments. Only time will tell if the increasing use of the Internet will foster post-national identities or dismantle the 'global village.' 


\subsection{Europeanised National Public Spheres: The Current State of Play}

Most scholars have settled on the notion of the 'Europeanisation of national public spheres.' In other words, Europeanisation takes national public spheres as starting points for the emergence of European identity. Most scholars accept that some modest form of Europeanisation is taking place within national publics spheres, particularly, in terms of increasing EU coverage and converging frames of reference. However, it would be a speculative to assume that a European identity would emerge on this basis. The media are heavily embedded in national institutional structures. As a result, EU news is reported with a heavy national accent. Indeed, several studies support this claim, most notably, Medrano's study (2003) which shows the dominance of national frames (see also Bijsmans \& Altides, 2007). This has led some scholars to describe the Europeanised public sphere as nationally 'segmented' (Wessler et al., 2008). The Internet does not seem to alter this dynamic. Even in cyberspace, studies have shown that these spaces are nationally embedded (Barisione \& Michailidou, 2017; Koopmans \& Zimmermann, 2003). In short, both online and offline spaces tend to tell European stories through a national filter.

The logic of mass-media reporting means that there is little prospect of national frames disappearing in the foreseeable future. The media are institutionally and culturally structured along national lines; therefore, they are hardwired to evoke national identity and frame stories in ways that appeal to national audiences. With reference to news value research, we can begin to understand why national frames persist. The media scholar (Schulz, 1982, as cited in de Wilde, 2019, p. 1196) proposed four criteria which determine 'newsworthiness': valence (i.e., controversy, aggression, success, values); identification (i.e., ethnocentrism, emotions, personalisation); relevance (i.e., concern, consequence, proximity); and status (i.e., elites, leaders). As national media outlets mainly cater to national audiences, the former are likely to evoke national identity as it is the most salient identity to the reader/listener. Indeed, one study has shown that the 'we' tends to be the nation (Kleinen-von Königslöw, 2010). Mass media are more likely to report on national executives (status) and domestic actor/issues (relevance) that the reader can relate to. Eurosceptic actors are also expected to receive a disproportionate level of attention because they tend to fuel controversy (valence). De Wilde (2019) rightly argues that these criteria should also apply to politicians given that their political claims propensity to resonate with wider audiences largely hinges on the mass media. Identity-politics can thus be understood as a logical and successful media strategy as political claims that lack an identitarian component contain less news value. This has led de Wilde (2019) to hypothesise that increasing media coverage of EU affairs could actually strengthen national identities. He convincingly argues that media logic functions to empower what he calls 'discursive intergovernmentalism,' that is, the media portraying the EU as a zerosum game between nations rather than a project of common endeavour. In short, the mass media are likely to be an impediment to a consolidated Europeanised public sphere and ergo European identity (de Wilde, 2019).

Public spheres are highly fragmented, and this applies to the local, national, and European level. This implies that public opinion and will formation are also fragmented. The EU consists of 27 nation-states containing their own nationally structured and culturally embedded news outlets speaking different vernaculars. 'Europe' is constructed differently within and across countries and varies according to the type of medium and media outlet. It is not unreasonable to claim that Europeanised public spheres are probably even more fragmented than national ones as there are over 27 different national 'narrative networks' (Eder, 2009) to reconcile. And, recent evidence suggests that there is little prospect of national cleavages coalescing into transnational coalitions of collective action. In contrast, national public spheres possess the legitimising glue of national identity and pre-existing cultural, political, and media institutions to bind these fragmented narratives together. Moreover, previous research has shown that negative valence of the EU and national indexicality are more prevalent in 'tabloid' vis-à-vis 'quality' newspapers (Kleinen-von Königs(öw, 2010). In contrast, quality newspapers are more likely to adopt European frames of reference and support European integration (Trenz, 2008a). These differences have contributed to the social stratification of support for European integration as poorer and uneducated people are the tabloids main market. The importance of social class as a predictor for EU support is wellknown in the scholarship on public opinion. This fragmentation has culminated in a discernible mismatch between elite perceptions of Europe and the general public (Medrano, 2009).

\section{Information Disorder: A Disruptive Factor of the Public Sphere?}

Epistemological inquiries into the nature of knowledge and truth, and human comprehension thereof, are as old as time. Yet it seems recent political events such as Brexit and the election of Donald Trump have brought the importance of truth in public discourse to the forefront. Since then, the study of 'information disorder' has become a burgeoning field of study. Information disorder is the trinity of 'disinformation' (i.e., the deliberate intent to spread false information), 'misinformation' (i.e., the accidental spreading of false information) and 'malinformation' (i.e., true information spread with the intent to cause harm; Corcoran et al., 2019). The observations we made earlier-namely, the rise of identity politics, increasingly politicised European debates, and the non-actualisation of a strong European identity-can be 
partially attributed to disruptive information. Claiming that the process of communication is imperfect is not a novel assertion, but some of the recent scholarship on how 'information disorder' can disrupt discourse and democracy, may help to explain why a strong European identity has proved elusive. These studies highlight that the manner in which people acquire, process and store new information, does not appear to be congruent with the congealment of a European identity.

Much of the scholarship on information disorder revolves around social media. Though there are many potential components of a digitalised public sphere (news websites, blogs, vlogs, instant messaging apps), the three major contemporary social media networks (Twitter, Facebook, Instagram) weigh heavily on both polemics and research of contemporary media influence. This may prove to be an overestimation, but in an assessment of a potential Europeanised public sphere, the impact of social media should not be overlooked. Social media have the potential to foster transnational communication; their influence and embeddedness with traditional media, and their widespread adoption as an instrument of political communication (Klašnja, Barberá, Beauchamp, Nagler, \& Tucker, 2018) make them crucial to the emergence of transnational identity. Of course, the popularity of utilising social media for 'information campaigns' (which target the EU) is a decisive factor as well (Bradshaw \& Howard, 2019); the latter can be regarded as one of the main compounding factors for the Europeanised public spheres' woes. This is where the dichotomy of the 'EU' and 'Europe' becomes important. Travelling and having friends abroad can significantly shape one's attachment to 'Europe,' but it is the 'EU' that has been, and still is, a major point of contention in the process Europeanisation.

False narratives have been part of the discourse on the EU for decades, but social media in particular have the potential to be influential in this regard. It remains an open question whether media actually have any influence, in general, and social media, in particular. This article has already ascribed a modest role to traditional media in fostering Europeanisation. In a similar vein, recent studies on the effects of disinformation in the European elections and the 2016 US Presidential elections are cautious in overstating the influence of disinformation on social media (Alcott \& Gentzkow, 2017; Fletcher, Cornia, Graves, \& Kleis Nielsen, 2018). This, thus, begs the question: Why would social media and information disorder be deemed potentially pernicious to the congealment of a Europeanised public sphere? Because information disorder has the potential to unravel the social fabric and weaken the social capital of the public sphere itself by casting doubt on the existence of truth and accountability. Though the peddling of false narratives in traditional media cannot be excluded, editorial responsibility and journalistic standards, at least, ensure minimum levels of accountability which are not present in social media. As Klinger and Svensson (2014) have argued, so- cial media follows a different logic than traditional media. Direct links between content creators and their audiences are made possible, and even encouraged, since popularity increases the visibility and resonance of content. Social media logic gives precedence to virality over factuality, which can prove disruptive when the topic of discussion is something as complex as the EU. There is the danger of emotive language and simplified narratives predominating.

Social media utilise cognitive principles with quick and short messages that often contain more emotionally charged content than traditional (news) media. Social media's reach may still not be as big as the latter, but their influence is growing. The EU is aware of information disorder's pernicious effects on the media landscape, as demonstrated by the many fact-checking initiatives it supports, such as EUvsDisinfo. In spite of these efforts, countering information disorder with facts has not proven sufficient to negate false narratives (de Cock Buning et al., 2018). However, studies have shown that informing people of the existence of manipulative and false information makes them better equipped to identify false narratives (Roozenbeek, van der Linden, \& Nygren, 2020), suggesting that it is not all doom and gloom for contemporary public spheres. Research has shown that negative information travels faster and further, which is more commensurate to the strategies and frames used by Eurosceptic politicians and the media (Balahur, Flore, Podavini, \& Verile, 2019). Moreover, the complexity of European politics and the potential economic benefits deriving from membership do not necessarily translate into appealing and acceptable media content. Compounding matters is the EU's constitutional and organisational complexity which makes it more vulnerable to misunderstanding and thus to misinformation. Combined with the human propensity to retain the first information that one consumes on a given topic and heuristics that favour modifying new information to fit pre-existing beliefs (Southwell et al., 2017), one could argue that there is a home advantage for national identity over the more abstract and nascent European identity. With the above in mind, information disorder should be considered as an inherent part of the Europeanised public sphere since both the spread and processing of information cannot preclude the dissemination of falsehoods.

\section{Conclusion}

It was expected that the increasing coverage of EU affairs in national public spheres would eventually lead to a greater sense of European belonging. Although the public sphere and mass media were pivotal to the development and sustenance of a nationally imagined community, there are compelling reasons to doubt whether a similar dynamic would hold in a transnational setting. Identity is a multifaceted and multifactorial phenomenon; it is understood both as a product of national public discourses, but also as a determinant 
of Europeanised public spheres. However, as Checkel (2014) aptly reminds us, the public sphere is only one locus where identity can be constructed. Transnational exchanges at the micro level also help to foster identification with Europe. In short, we endorse Checkel's (2014) view for advocating a more comprehensive approach to identity as created through social communication (providing that the right scope conditions are in place) and social contact (as in Deutsch, 1966). With this in mind, we argue that establishing linear relationships predicated on the public sphere alone is a perilous route to take. The current deliberative setting of the public sphere is not commensurate to a collective EU identity. Politicisation has expanded the scope of conflict to other actors such as Eurosceptics. The Internet has enfranchised new actors from outside Europe to infiltrate the Europeanised public sphere more easily. Furthermore, cyberspace has demonstrated to be a hotbed for fuelling Euroscepticism and polarising discourse. And, as previous scholars have theorised and demonstrated empirically, these divisions are predominantly structured along the cultural-identitarian dimension. With the rise of identity politics, political parties are evoking stronger and more salient national identities to mobilise support. Moreover, we argue that the preponderance of constitutive contestation is likely to hamper support for the EU and feelings of attachment towards Europe. Although we acknowledge that people can hold multiple inclusive identities, it does not follow that all identities are of this kind. It is not national identity per se but exclusive kinds which have negative implications for European levels of attachment. Lastly, Europeanised public spheres are nationally segmented and highly fragmented. Social media and the rising tide of information disorder have exacerbated this dynamic through their exploitation of human cognitive functions and prioritising virality over factuality. Due to the embeddedness of online and offline media within national structures, and a nationally entrenched media logic, there are meagre prospects of this changing in the near future. A healthy public sphere should therefore account for more than factual discourse alone in order to foster a European identity.

\section{Acknowledgments}

The authors would like to express their gratitude to the Academic Editors of this thematic issue for their interest in this article, as well as their support and friendship both inside and outside the confines of academia.

\section{Conflict of Interests}

The authors declare no conflict of interests.

\section{References}

Adam, L. B. (2012). The significance of EU topics in national media: Has there been an Europeanization of reporting in the national media? (Bruges Political Research Papers 27). Bruges: College of Europe.

Alcott, H., \& Gentzkow, M. (2017). Social media and fake news in the 2016 election. Journal of Economic Perspectives, 31(2), 211-236.

Anderson, B. (1983). Imagined communities. New York, NY: Verso.

Anderson, C. J., \& Kaltenthaler, K. C. (2001). Europeans and their money: Explaining public support for the common European currency. European Journal of Political Research, 40(2), 139-170.

Balahur, A., Flore, M., Podavini, A., \& Verile, M. (2019). Understanding citizens' vulnerabilities to disinformation and data-driven propaganda. Brussels: Publications Office of the European Union.

Bärenreuter, C., Brüll, C., Mokre, M., \& Wahl-Jorgensen, K. (2009). An overview of research on the European public sphere (Online Working Paper No. 03). Vienna: EUROSPHERE.

Barisione, M., \& Michailidou, A. (2017). Social media and European politics: Rethinking power and legitimacy in the digital era. London: Palgrave Macmillan.

Bartolini, S., \& Hix, S. (2006). Politics: The right or the wrong sort of medicine for the EU? Paris: Notre Europe.

Bijsmans, P., \& Altides, C. (2007). 'Bridging the Gap' between EU politics and citizens? The European Commission, national media and EU affairs in the public sphere. Journal of European Integration, 29(3), 323-340.

Billig, M. (1995). Banal nationalism. London: Sage Publications.

Bossetta, M., \& Segesten, A. D. (2019). Can euroscepticism contribute to a European public sphere? The europeanization of media discourses on euroscepticism across six countries. Journal of Common Market Studies, 57(5), 1051-1070.

Bradshaw, S., \& Howard, P. N. (2019). 2019 global inventory of organised social media manipulation (Working Paper 2019). Oxford: Oxford Internet Institute.

Brantner, C., Dietrich, A., \& Saurwein, F. (2005). Europeanisation of national public spheres: Empirical evidence from Austria. Paper presented at the First European Communication Conference, Amsterdam, The Netherlands.

Bruter, M. (2003). Winning hearts and minds for Europe: The impact of news and symbols on civic and cultural European identity. Comparative Political Studies, 36(10), 1148-1179.

Bruter, M. (2005). Citizens of Europe? The emergence of a mass European identity. New York, NY: Palgrave Macmillan.

Caiani, M., \& Parenti, L. (2009). The dark side of the web: Italian right-wing extremist groups and the Internet. South European Society and Politics, 14(3), 273-294.

Cerulus, L. (2015, January 8). Social media favours eurosceptics in EU elections. Euractiv. Retrieved from https://www.euractiv.com/section/digital/news/ social-media-favours-eurosceptics-in-eu-elections 
Checkel, J. (2014). Identity, Europe, and the world beyond public spheres. In T. Risse (Ed.), European public spheres: Politics is back (pp. 227-246). Cambridge: Cambridge University Press.

Christensen, D. (1996). The left-wing opposition in Denmark, Norway and Sweden: Cases of Euro-phobia. West European Politics, 19(3), 525-546.

Cinpoes, R. (2008). Thematic articles: National identity and European identity. Journal of Identity and Migration Studies, 2(1), 3-14.

Citrin, J., \& Sides, J. (2004). More than nationals: How identity choice matters in the new Europe. In R. K. Herrmann (Ed.), Transnational identities: Becoming European in the EU (pp. 161-185). Lanham: Rowman \& Littlefield.

Cohen, R. (1994). Frontiers of identity: The British and the others. London: Longman.

Corcoran, C., DiResta, R., Morar, D., Honke, G., Sullivan, D., Dhamani, N., . . Ruppel, B. (2019). Disinformation: Detect to disrupt. Paper presented at the Conference for Truth and Trust Online 2019, London, UK.

de Cock Buning, M., Raag, I., Bechmann, A., Nielsen, R., Markovski, V., Jimenez Cruz, C., . . . van Wijk, W. (2018). A multi-dimensional approach to disinformation: Report of the independent high-level group on fake news and online disinformation. Brussels: European Commission.

de Vreese, C. H., \& Kandyla, A. (2009). News framing and public support for a common foreign and security policy. Journal of Common Market Studies, 47(3), 453-481.

de Wilde, P. (2019). Media logic and grand theories of European integration. Journal of European Public Policy, 26(8), 1193-1212.

de Wilde, P., \& Leupold, A. (2015). Introduction: The differentiated politicisation of European governance. West European Politics, 39(1), 3-22.

de Wilde, P., \& Trenz, H.-J. (2012). Denouncing European integration: Euroscepticism as polity contestation. European Journal of Social Theory, 15(4), 537-554.

Deflen, M., \& Pampel, F. C. (1996). The myth of postnational identity: Popular support for European unification. Social Forces, 75(1), 119-143.

Delanty, G. (2005). The quest for European identity. In E. Eriksen (Ed.), Making the European polity: Reflexive integration in the EU (pp. 127-142). London: Routledge.

Della Porta, D., \& Mosca, L. (2006). Globalization from below: Transnational activists and protest networks. Minneapolis, MN: University of Minnesota Press.

Derman, D., \& Ross, K. (2003). Mapping the margins: Identity, politics, and the media. Cresskill, NJ: Hampton Press.

Derrida, J. (1988). Signature event context. Evanston, IL: Northwestern University Press.

Deutsch, K. (1966). Nationalism and social communication. Cambridge, MA: MIT Press.
Dewey, J. (1927). The public and its problems. New York, NY: Holt.

Diamandaki, K. (2003). Virtual ethnicity and digital diasporas: Identity construction in cyberspace. Global Media Journal, 2(2), 1-14.

Eder, K. (2009). A theory of collective identity making sense of the debate on a 'European identity.' European Journal of Social Theory, 12(4), 427-447.

Eder, K., \& Kantner, C. (2000). Transnational Resonanzstrukturen in Europa: Eine Kritik der Rede vom Öffentlichkeitsdefizit [Transnational resonance structures in Europe: A critique of the 'publicness deficit' speech]. In M. Bach (Ed.), Die Europäisierung nationaler Gesellschaften [The Europeanization of national societies] (pp. 306-331). Wiesbaden: Westdeutscher Verlag.

Eilders, C., \& Lichtenstein, D. (2010). Diskursive Konstruktionen von Europa: Eine Integration von Öffentlichkeits: und Identitätsforschung [Discursive constructions of Europe: An integration of public sphere and identity research]. Medien \& Kommunikationswissenschaft, 58(2), 190-207.

Eriksen, E. O. (2007). Conceptualising European public spheres: General, segmented and strong publics. In J. E. Fossum \& P. Schlesinger (Eds.), The European Union and the public sphere: A communicative space in the making? (pp. 23-43). Oxford: Routledge.

Eriksen, T. H. (2007). Nationalism and the Internet. Nations and Nationalism, 13(1), 1-17.

Fearon, J. D., \& Laitin, D. D. (2000). Violence and the social construction of ethnic identity. International Organization, 54(4), 845-877.

Fletcher, R., Cornia, A., Graves, L., \& Kleis Nielsen, R. (2018). Measuring the reach of "fake news" and online disinformation in Europe (Factsheet 2018). Oxford: Reuters Institute.

Follesdal, A. (2014). Democracy, identity, and European public spheres. In T. Risse (Ed.), European Public spheres: Politics is back (pp. 247-262). Cambridge: Cambridge University Press.

Fossum, J. E., \& Schlesinger, P. (2007). The European Union and the public sphere: A communicatitve space in the making? Oxon: Routledge.

Gellner, E. (2006). Nations and nationalism. Malden, MA: Blackwell Publishing.

Gidişoğlu, S., \& Rızvanoğlu, K. (2011). Nationalism on the Internet: A discursive analysis of the Turkish case. Boğaziçi Journal, 25(2), 83-107.

Grill, C., \& Boomgaarden, H. (2017). A network perspective on mediated Europeanized public spheres: Assessing the degree of Europeanized media coverage in light of the 2014 European Parliament election. European Journal of Communication, 32(6), 568-582.

Haas, E. (1958). The uniting of Europe: Political, social, and economic forces 1950-1957. Stanford, CA: Stanford University Press.

Habermas, J. (1991). Structural transformation of the public sphere: An inquiry into a category of bourgeois 
society. Cambridge, MA: MIT Press.

Habermas, J. (2012). The crisis of the European Union: $A$ response. Cambridge: Polity Press.

Hänska, M., \& Bauchowitz, S. (2019). Can social media facilitate a European public sphere? Transnational communication and the Europeanization of Twitter during the Eurozone crisis. Social Media + Society, 5(3), $1-14$.

Heller, M., \& Rényi, Á. (2008). EU enlargement, identity and the public sphere. In P. Schlesinger \& J. E. Fossum (Eds.), The European Union and the public sphere (pp. 169-186). Cambridge: Cambridge University Press.

Hennen, L., Van Keulen, I., Korthagen, I., Aichholzer, G., Lindner, R., \& Nielsen, R. $\varnothing$. (Eds.). (2020). European e-democracy in practice. Switzerland: SpringerOpen.

Hooghe, L., \& Marks, G. (2017). Cleavage theory meets Europe's crises: Lipset, Rokkan, and the transnational cleavage. Journal of European Public Policy, 25(1), 109-135.

Kantner, C. (2015). National media as transnational discourse arenas: The case of humanitarian military interventions. In T. Risse (Ed.), European public spheres: Politics is back (pp. 84-107). Cambridge: Cambridge University Press.

Kantner, C. (2016). War and intervention in the transnational public sphere. Oxford: Routledge.

Klašnja, M., Barberá, P., Beauchamp, N., Nagler, J., \& Tucker, J. A. (2018). Measuring public opinion with social media data. In L. R. Atkeson \& R. M. Alvarez (Eds.), The Oxford handbook of polling and survey methods (pp. 555-582). Oxford: Oxford University Press.

Kleinen-von Königslöw, K. (2010). Europe for the people? The Europeanization of public spheres in the tabloid press. In T. Lindenberger (Ed.), European history and public spheres (pp. 44-61). Vienna: StudienVerlag.

Klinger, U., \& Svensson, J. (2014). The emergence of network media logic in political communication: A theoretical approach. New Media \& Society, 17(8), 1-17.

Klingeren, V., \& Boomgaarden, H. (2014). The strength of exclusive national identity is the most important indicator of Euroscepticism. LSE Blogs. Retrieved from https://blogs.Ise.ac.uk/europpblog/2014/02/ 13/the-strength-of-an-individuals-national-identityis-the-most-important-indicator-of-euroscepticism

Koopmans, R., \& Pfetsch, B. (2003). Towards a Europeanised public sphere? Comparing political actors and the media in Germany (ARENA Working Paper 23/03). Oslo: Centre for European Studies.

Koopmans, R., \& Statham, P. (2010). The making of a European Public Sphere. Cambridge: Cambridge University Press.

Koopmans, R., \& Zimmermann, A. C. (2003). Internet: A new potential for European political communication? (WZB Discussion Paper, No. SP IV 2003-402). Berlin: WZB Berlin Social Science Center.

Kriesi, H., \& Grande, E. (2006). Globalization and the transformation of the national political space: Six European countries compared. European Journal of Po- litical Research, 45(6), 921-956.

Kriesi, H., \& Grande, E. (2008). West European politics in the age of globalization. Cambridge: Cambridge University Press.

Kriesi, H., \& Grande, E. (2012). Political conflict in western Europe. Cambridge: Cambridge University Press.

Kriesi, H., \& Grande, E. (2014). The Europeanization of the national political debate. In O. Cramme \& S. B. Hobolt (Eds.), Democratic politics in a European Union under stress (pp. 67-86). Oxford: Oxford University Press.

Lindner, R., Korthagen, I., \& Aichholzer, G. (2018). Prospects for e-democracy in Europe Part I: Literature review. Brussels: European Parliamentary Research Service.

Loseke, D. R. (2007). The study of identity as cultural, institutional, organizational, and personal narratives: Theoretical and empirical integrations. The Sociological Quarterly, 48(4), 661-688.

Machill, M., Beiler, M., \& Fischer, C. (2006). Europetopics in Europe's media: The debate about the European public sphere: A meta-analysis of media content analyses. European Journal of Communication, 21(1), 57-88.

MacMillan, C. (2013). Discourse, identity and the question of Turkish accession to the EU. Surrey: Ashgate.

Marks, G. (1999). Territorial identities in the European Union. In J. J. Anderson (Ed.), Regional integration and democracy: Expanding on the European experience (pp. 69-91). Lanham, MD: Rowman \& Littlefield.

Marks, G., \& Hooghe, L. (2003). National identity and support for European integration (WZB Discussion Paper, No. SP IV 2003-202). Berlin: WZB Berlin Social Science Center.

McLuhan, M. (1964). Understanding media: The extensions of man. New York, NY: Signet Books.

Medrano, D. (2003). Framing Europe: Attitudes to European integration in Germany, Spain, and the United Kingdom. Princeton, NJ: Princeton University Press.

Medrano, J. D. (2009). The public sphere and the European Union's political identity. In J. T. Checkel \& P. J. Katzenstein (Eds.), European Identity (pp. 81-110). Cambridge: Cambridge University Press.

Medrano, J. D., \& Gray, E. (2010). Framing the European Union in national public spheres. In R. Koopmans \& P. Statham (Eds), The making of a European public sphere: Media discourse and political contention (pp. 195-219). Cambridge: Cambridge University Press.

Medrano, J. D., \& Gutiérrez, P. (2001). Nested identities: National and European identity in Spain. Ethnic and Racial Studies, 24(5), 753-778.

Miller, D., \& Slater, D. (2001). The Internet: An ethnographic approach. Berkeley, CA: Bloomsbury Academic.

Mouffe, C. (2007). Art and democracy: Art as an agonistic intervention in public space. In C. Mouffe (Ed.), Art and research: A journal of ideas, context and methods (pp. 6-15). Rotterdam: NAi Publishers. 
Nitoiu, C. (2013). The European public sphere: Myth, reality or aspiration? Political Studies Review, 11(1), 26-38.

Olausson, U. (2010). Towards a European identity? The news media and the case of climate change. European Journal of Communication, 25(2), 138-152.

Pfetsch, B. (2004). The voice of the media in European public sphere: Comparative analysis of newspaper editorials (Integrated Report WP 3). Berlin: Europub.

Pfetsch, B. (2005). National media in Europeanized public sphere: The openness and support of the press for European integration. In C. de Vreese \& $\mathrm{H}$. Schmitt (Eds.), A European public sphere: How much of it do we have and how much do we need? (pp. 401-425). Mannheim: The Mannheim Centre for European Social Research.

Risse, T. (2010). A community of Europeans? Transnational identities and public spheres. Ithaca, NY: Cornell University Press.

Risse, T. (Ed.). (2014). European public spheres: Politics is back. Cambridge: Cambridge University Press.

Roozenbeek, J., van der Linden, S., \& Nygren, T. (2020). Prebunking interventions based on "inoculation" theory can reduce susceptibility to misinformation across cultures. The Harvard Kennedy School Misinformation Review, 1(2), 1-23.

Scalise, G. (2013). European identity construction in the public sphere: A case study of narratives of Europe. International Journal of Cross-Cultural Studies and Environmental Communication, 2(2), 51-62.

Schuck, A. R., \& de Vreese, C. H. (2006). Between risk and opportunity: News framing and its effects on public support for EU enlargement. European Journal of Communication, 21(1), 5-32.

Sicakkan, H. G. (2012). EUROSPHERE: Diversity and the European public sphere towards a citizens' Europe. Budapest: EUROSPHERE.

Smith, A. D. (1992). National identity and the idea of European unity. International Affairs, 68(1), 55-76.

Southwell, B. G., Thorson, E. A., \& Sheble, L. (2017). The persistence and peril of misinformation. American Scientist, 105(6), 368-371.

Statham, P. (2007). Political communication, European integration and the transformation of national public spheres: A comparison of Britain and France. In J. E. Fossum \& P. Schlesinger (Eds.), The European Union and the public sphere (pp. 110-134). Oxford:
Routledge.

Taggart, P. (1998). A touchstone of dissent: Euroscepticism in contemporary Western European party systems. European Journal of Political Research, 33, 363-388.

Thomassen, J. (2009). The legitimacy of the European Union after enlargement. Oxford: Oxford University Press.

Trenz, H.-J. (2008a). 'Quo vadis Europe?': Quality newspapers struggling for European unity. In P. Schlesinger \& J. E. Fossum (Eds.), The European Union and the public sphere (pp. 89-109). London: Routledge.

Trenz, H.-J. (2008b). Measuring the Europeanisation of public communication: The question of standards. European Political Science, 7(3), 273-284.

Triga, V., \& Vadratsikas, K. (2018). The impact of media representations of the $\mathrm{EU}$ and its policies on European identity (Cohesify Research Paper). Cyprus: COHESIFY.

Valentini, C. (2006). Constructing public support: EU communication challenges for the process of integration for the process of integration. Paper presented at the International Conference "Public Spheres and their boundaries," Tampere, Finland.

Van Cauwenberghe, A., Gelders, D., \& Joris, W. (2009). Covering the European Union: From an intergovernmental towards a supranational perspective? Javnost: The Public, 16(4), 41-54.

van Os, R. (2005). Framing Europe online: French political parties and the European election of 2004. Information Polity, 10(3/4), 205-218.

Voltmer, K., \& Eilders, C. (2003). The media agenda: The marginalization and domestication of Europe. In $\mathrm{K}$. Dyson \& K. Goetz (Eds.), Germany, Europe, and the politics of constraint (pp. 173-199). Oxford: Oxford University Press.

Wenzel, M., \& Mummendey, A., \& Waldzus, S. (2007). Superordinate identities and intergroup conflict: The ingroup projection model. European Review of Social Psychology, 18, 331-372.

Wessler, H., Peters, B., Brüggemann, M., Kleinen-von Königslöw, K., \& Sifft, S. (2008). Transnationalization of public spheres. Basingstoke: Palgrave MacMillan.

Wodak, R. (2007). 'Doing Europe': The discursive construction of European identities. In R. C. Mole (Ed.), Discursive constructions of identity in European politics (pp. 70-95). New York, NY: Palgrave Macmillan.

\section{About the Authors}

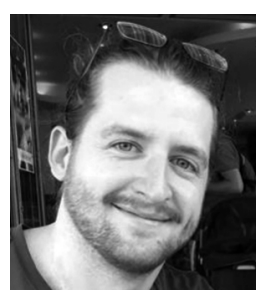

Jan Erik Kermer is a PhD Student in Political Science at LUISS Guido Carli University in Rome, Italy. Jan's PhD project aims to examine whether the Europeanisation of national debates has fostered, paradoxically, the national public spheres' (re-)nationalisation. His wider research interests include the studies of Euroscepticism, populism, identity politics, and exploring the effects of mass media and social media on voting behaviour. 


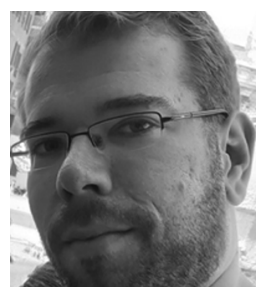

Rolf A. Nijmeijer is a PhD Student in Political Science at LUISS Guido Carli University in Rome, Italy. It is the objective of his doctoral research project to identify to what extent the content of disinformation campaigns on social media is adapted to match unique characteristics of the societies that they target. In addition to information disorder and social media, his research interests include propaganda, public opinion, and political behaviour. 